\title{
Phytoprotection
}

\section{The location of egg masses of Ostrinia nubilalis [Lepidoptera : Pyralidae] on potato plants}

\section{A.P. Dornan et J.G. Stewart}

Volume 76, numéro 3, 1995

URI : https://id.erudit.org/iderudit/706091ar

DOI : https://doi.org/10.7202/706091ar

Aller au sommaire du numéro

Éditeur(s)

Société de protection des plantes du Québec (SPPQ)l

ISSN

0031-9511 (imprimé)

1710-1603 (numérique)

Découvrir la revue

Citer cet article

Dornan, A. \& Stewart, J. (1995). The location of egg masses of Ostrinia nubilalis [Lepidoptera : Pyralidae] on potato plants. Phytoprotection, 76(3), 123-126. https://doi.org/10.7202/706091ar
Résumé de l'article

La position des masses d'oeufs de la pyrale du maïs, Ostrinia nubilalis, a été étudiée sur des pommes de terre (Solanum tuberosum) 'Russet Burbank' cultivées à l'île-du-Prince-Édouard (Canada) de 1990 à 1992. La position sur la plante de 315 masses d'oeufs a été caractérisée par l'examen d'environ 3700 plantes. Dans le deux tiers inférieur des plantes se retrouvaient $92 \%$ des masses d'oeufs, tandis que $95 \%$ des masses d'oeufs se localisaient sur la face inférieure des folioles et sur les tiges. Dans l'ensemble, $88 \%$ des masses d'oeufs se retrouvaient dans le deux tiers inférieur des plantes, à la fois sur les tiges et sur la face inférieure des folioles. La période d'échantillonnage pourra être optimisée si les personnes qui effectuent le dépistage concentrent leurs efforts seulement sur le deux tiers inférieur des tiges, lequel représente seulement 3,7 $\%$ de la surface totale de la fane mais contient $50 \%$ des masses d'oeufs. 


\title{
Communication brève / Short communication The location of egg masses of Ostrinia nubilalis
[Lepidoptera : Pyralidae] on potato plants
}

\author{
Andrew P. Dornan and Jeff G. Stewart ${ }^{1}$
}

Received 1994-08-11; 1995-11-27

The location of egg masses of the European corn borer, Ostrinia nubilalis, was studied on potatoes (Solanum tuberosum) 'Russet Burbank' grown on Prince Edward Island, Canada, from 1990 to 1992. The within-plant positions of 315 egg masses were characterized by the examination of approximately 3700 plants. Ninety-two percent of the egg masses were found on the bottom twothirds of the plants and $95 \%$ were found on the underside of the leaflets and on the stalks. In total, $88 \%$ of the egg masses were found on the bottom twothirds of the plants on both the stalks and the underside of the leaflets. Sampling time can be optimized if the people engaged in scouting programs concentrate their efforts on the bottom two-thirds of the stalks alone, which represents only $3.7 \%$ of the total surface area of the haulm but contains $50 \%$ of the egg masses.

Dornan, A.P. et J.G. Stewart. 1995. Position des masses d'oeufs de l'Ostrinia nubilalis [Lepidoptera : Pyralidae] sur des plantes de pomme de terre. PHYTOPROTECTION 76 : 123-126.

La position des masses d'oeufs de la pyrale du maïs, Ostrinia nubilalis, a été étudiée sur des pommes de terre (Solanum tuberosum) 'Russet Burbank' cultivées à l'île-du-Prince-Édouard (Canada) de 1990 à 1992. La position sur la plante de 315 masses d'oeufs a été caractérisée par l'examen d'environ 3700 plantes. Dans le deux tiers inférieur des plantes se retrouvaient $92 \%$ des masses d'oeufs, tandis que $95 \%$ des masses d'oeufs se localisaient sur la face inférieure des folioles et sur les tiges. Dans l'ensemble, $88 \%$ des masses d'oeufs se retrouvaient dans le deux tiers inférieur des plantes, à la fois sur les tiges et sur la face inférieure des folioles. La période d'échantillonnage pourra être optimisée si les personnes qui effectuent le dépistage concentrent leurs efforts seulement sur le deux tiers inférieur des tiges, lequel représente seulement 3,7 \% de la surface totale de la fane mais contient $50 \%$ des masses d'oeufs.

The European corn borer, Ostrinia nubilalis (Hübner) [Lepidoptera : Pyralidae], is well known as an important pest of corn (Zea mays L.) in most of North America. With a host range of over 200 other species of plants (Hodgson 1928), it is not surprising that this insect has proven to be an important pest of potatoes (Solanum tuberosum L.) grown on Prince Edward Island (Stewart 1992). Larvae damage potatoes by burrowing into the stalk and destroying much of the pith, xylem, and phloem (Kennedy and Anderson 1980). Infestations that reached a

1. Agriculture and Agri-Food Canada, Research Centre, P.O. Box 1210, Charlottetown, Prince Edward Island, Canada C1A 7M8. Contribution No. 827 
seasonal average of 1.2 larvae haulm ${ }^{-1}$ reduced total and marketable yields of 'Russet Burbank' potatoes on Prince Edward Island by 8 and $9 \%$, respectively (Stewart 1992). Infested plants are also more susceptible to wind damage, water stress, and pathogens such as Erwinia carotovora var. atroseptica (van Hall) (Kennedy 1983).

In order to control the European corn borer with insecticides, foliar applications have to be made just after the eggs hatch and before the larvae burrow into the stalk. When the larvae enter the stalk, insecticides applied to the crop are usually ineffective (Dill and Jones 1984). The monitoring of adult populations alone is not a reliable indicator to predict damage in nearby fields (Dornan and Stewart 1995). Therefore, the development of an economic threshold which minimizes yield losses due to damage by the European corn borer on potatoes will probably be based on counts of egg masses or early instars on plants.

Scouting for egg masses of the European corn borer is considered very difficult on potatoes and almost impossible on cotton (Gossypium hirsutum L.) (Savinelli 1984). A procedure exists for scouting egg masses of the European corn borer on corn (Calvin et al. 1986; Linker et al. 1990) but to this point, no procedures have been established for scouting egg masses on potatoes. The first step in the development of a sampling procedure is to characterize the location of egg masses on the potato plant. If scouts concentrate their time on the specific area of the plant where the majority of the egg masses are located, scouting effort can be optimized and sampling time reduced.

In this study, the within-plant distribution of egg masses on potato plants was determined by the examination of haulms (defined as including the main stem or stalk, secondary stalks, and all compound leaves including leaflets and petiolules) sampled in commercial fields of potato cv. Russet Burbank in four locations in the Eastern Prince (lat. $46^{\circ} 24^{\prime} \mathrm{N}$ long. $63^{\circ} 47^{\prime} \mathrm{W}$ ) and Western Queens (lat. $46^{\circ} 14^{\prime} \mathrm{N}$ long. $63^{\circ} 30^{\prime} \mathrm{W}$ ) counties of Prince Edward Island, each year from 1990 to 1992. Samples were taken during the approximately 4-wk period of European corn borer oviposition each year. Each site was sampled weekly from 16 July to 7 August in 1990, from 15 July to 8 August in 1991, and from 21 July to 16 August in 1992. Two randomly selected haulms per plant, for a total of at least 240 haulms, were examined at each site. Plants were sampled at random and the two haulms were divided into three more or less equal vertical strata based on the length of the stalk (defined as the main stem and secondary stems without compound leaves) and designated as "top", "middle", and "bottom". Egg masses within each vertical strata were further characterized as being either on the stalk, or the upperor undersurface of the leaflet (including petiolule).

In 1994, 30 haulms of cv. Russet Burbank potatoes were randomly selected from research plots during the approximate period of European corn borer oviposition. These plots were kept free of insect pests with bi-weekly applications of insecticides. Each haulm was cut into "top", "middle" and "bottom", based on the length of the stalk. The surface areas of both upper- and underside of leaflets (including petiolules) as well as stalks were recorded using a Li-Cor area meter (Model L1-3000, Geneq Inc., IMontréal, Quebec) and are summarized in Table 1. By assuming a proportional distribution of egg masses based on available surface area (Table 1), a contingency table was constructed based on the frequency of occurrence of the total number of egg masses found on each of nine strata (Table 2). The data were analyzed with a chi-square $\left(X^{2}\right)$ test considered significant at $P \leq 0.05$ (Steel and Torrie 1980).

The population of European corn borer on Prince Edward Island is univoltine (Stewart 1994). Peak counts of egg masses occurred at approximately the end of July in each year when plants were in the pre-bloom stage or just beginning bloom. Canopy heights ranged from 22 to $67 \mathrm{~cm}$ during the period of oviposition each year. A total of $315 \mathrm{egg}$ masses of the European corn borer were found on approximately 3700 plants sampled over the $3 \mathrm{yr}$ of the study. An analysis of the frequency of occurrence of 
Table 1. Average surface area of 'Russet Burbank' potato haulms during the approximate period of European corn borer oviposition in 1994

\begin{tabular}{lccc}
\hline & \multicolumn{3}{c}{ Surface stratum $\left(\mathrm{cm}^{2}\right)$} \\
\cline { 2 - 4 } Vertical stratum & Leaflet upperside & Leaflet underside & Stalk \\
\hline Top third & $691.5 \pm 48.3^{\mathrm{a}}$ & $691.5 \pm 48.3$ & $39.5 \pm 2.4$ \\
Middle third & $1204.4 \pm 180.7$ & $1204.4 \pm 180.7$ & $82.7 \pm 7.2$ \\
Bottom third & $487.2 \pm 79.5$ & $487.2 \pm 79.5$ & $99.9 \pm 10.4$ \\
\hline
\end{tabular}

a Mean \pm standard error of the mean.

Table 2. Within-plant distribution of the total number of European corn borer egg masses on potato haulms

\begin{tabular}{|c|c|c|c|c|c|c|c|c|}
\hline \multirow{3}{*}{$\begin{array}{l}\text { Vertical } \\
\text { stratum }\end{array}$} & \multicolumn{7}{|c|}{ Surface stratum } & \multirow{3}{*}{$\begin{array}{c}\text { Total } \\
\text { (eggs haulm }{ }^{-1} \text { ) }\end{array}$} \\
\hline & \multicolumn{3}{|c|}{ Leaflet upperside } & \multicolumn{2}{|c|}{ Leaflet underside } & \multicolumn{2}{|c|}{ Stalk } & \\
\hline & leggs & haulm ${ }^{-1}$ & $(\exp . \text { freq. })^{a}$ & (eggs haulm ${ }^{-1}$ ) & (exp. freq.) & (eggs haulm ${ }^{-1}$ ) & (exp. freq.) & \\
\hline Top third & & 4 & 43.8 & 11 & 43.8 & 11 & 2.5 & 26 \\
\hline Middle thirc & & 5 & 75.9 & 57 & 75.9 & 79 & 5.2 & 141 \\
\hline Bottom thir & & 6 & 30.8 & 63 & 30.8 & 79 & 6.3 & 148 \\
\hline Total & & 15 & - & 131 & - & 169 & - & 315 \\
\hline
\end{tabular}

${ }^{a}$ Expected frequencies of egg masses if they were proportionally distributed on potato plants according to surface area, $X^{2}=2100.04, \mathrm{df}=8, P<0.001$.

egg masses showed that the distribution of egg masses was not proportional to available surface area $\left(X^{2}=2100.04, \mathrm{df}=\right.$ $8, P<0.001)$. In fact, when averaged over each vertical stratum, $92 \%$ of the total number of egg masses were distributed on the bottom two strata of the plants (Table 2). We speculate that the females are selecting for the lower portion of the plants both for increased protection from desiccation and the more moderate microclimate in the foliage at this level.

When averaged over different surfaces of the plant, $95 \%$ of the egg masses were distributed between the underside of the leaflets and the stalks (Table 2). We speculated that oviposition on the upper surface of the leaflet would not be very advantageous because of susceptibility to desiccation, rainfall, and increased visibility to predators. Oviposition on the stalks would be advantageous because of the closer proximity of entry sites for the larvae. Of the total number of egg masses classified both by vertical and surface strata, $88 \%$ of egg masses were concentrated in only $38 \%$ of the total surface area of the haulm; on the lower two-thirds of the haulm, on either the underside of the leaflets or on the stalk (Table 2). Because of the difficulty involved with scouting for egg masses of the European corn borer on potatoes and the fact that relatively low numbers of egg masses can result in significant damage (Dornan and Stewart 1995), a reduction in the time spent sampling for egg masses of the European corn borer would be beneficial. These results suggest that sampling time can be reduced if the people engaged in scouting programs concentrate their efforts on the bottom two-thirds of the plants, on both the underside of the leaflets and on the stalks when sampling for the majority of the egg masses of the European corn borer.

The surface area of the stalk is considerably less than that of the underside of the foliage (Table 1). In fact, the surface area of the middle and lower stalk is only $3.7 \%$ of the total surface area; however, $50 \%$ of all the egg masses were found in this area. The contingency table analysis demonstrated no significant interaction 
between rows and columns $\left(X^{2}=5.4\right.$, $\mathrm{df}=4, P=0.25$ ) of Table 2 . Therefore, the information obtained from sampling both the stalks and undersides of the leaflets is no greater than that obtained from sampling stalks alone. Consequently, the most cost-effective method for sampling European corn borer egg masses on potatoes would be to sample only the middle and bottom thirds of the stalk area, which represents only $3.7 \%$ of the total surface area of the haulm but contains $50 \%$ of the egg masses.

\section{ACKNOWLEDGEMENTS}

We thank Sara Gormley and Irene Joostema for technical help and all the growers whose participation made this study possible. Funding was provided by a Canada/P.E.I. Cooperation Agreement on Agriculture, Sustainable Agriculture Development Program, Crop Development Sub-Program.

\section{REFERENCES}

Calvin, D.D., M.C. Knapp, K. Xingquan, F.L. Poston, and S.M. Welch. 1986. Using a decision model to optimize European corn borer [Lepidoptera: Pyralidae] egg mass sampling. Environ. Entomol. 15: 12121219.

Dill, J.F., and R.T. Jones 1984. European corn borer. IPM Potato Fact Sheet 107, Cooperative Extension Service University of Maine at Orono, 2 pp.

Dornan, A.P., and J.G. Stewart. 1995. Population dynamics of the European corn borer, Ostrinia nubilalis (Hübner)(Lepidoptera : Pyralidae) attacking potatoes in Prince Edward Island. Can. Entomol. 127 : 255262.
Hodgson, B.E. 1928. The host plants of the European corn borer. N. Engl. Bull. No. 77, U.S. Dep. Agric. : 1-63.

Kennedy, G.C. 1983. Effects of European corn borer [Lepidoptera : Pyralidae] damage on yields of spring-grown potatoes. J. Econ. Entomol. 76 : 316-332.

Kennedy, G.C., and T.E. Anderson. 1980. European corn borer trapping in North Carolina with various sex pheromone component blends. J. Econ. Entomol. 73: 642646.

Linker, H.M., J.W. Van Duyn, J.R., Anderson Jr., and W.M. Lewis. 1990. Scouting corn in North Carolina. N.C. Agric. Ext. Serv. Publ. Ag-399, 11 pp.

Savinelli, C.E. 1984. Ovipositional response, larval feeding behaviour, and injury assessment of the European corn borer, Ostrinia nubilalis (Hübner), to cotton in North Carolina. Ph.D. thesis, University of North Carolina, Raleigh. 152 pp.

Steel, G.D., and J.H. Torrie. 1980. Principles and procedures of statistics : a biometrical approach, $2^{\text {nd }}$ ed. McGraw-Hill, New York, $633 \mathrm{pp}$

Stewart, J.G. 1992. The European corn borer, Ostrinia nubilalis [Lepidoptera: Pyralidae] : a potential pest of potatoes grown on Prince Edward Island. Phytoprotection 73 : 25-29.

Stewart, J.G. 1994. Monitoring adult European corn borer [Lepidoptera : Pyralidae] in potatoes on Prince Edward Island. Environ. Entomol. 23 : 1124-1128. 